University of Nebraska - Lincoln

DigitalCommons@University of Nebraska - Lincoln

Faculty Publications from the Harold W. Manter Laboratory of Parasitology

9-20-1995

\title{
The Enterobiinae Subfam. Nov. (Nematoda, Oxyurida) Pinworm Parasites of Primates and Rodents
}

Jean-Pierre Hugot

hugot@cimrs1.nnhn.fr

Scott Lyell Gardner

University of Nebraska - Lincoln, slg@unl.edu

Serge Morand

Centre de Biologie et de Gestion des Populations, morand@ensam.inra.fr

Follow this and additional works at: https://digitalcommons.unl.edu/parasitologyfacpubs

Part of the Parasitology Commons

Hugot, Jean-Pierre; Gardner, Scott Lyell; and Morand, Serge, "The Enterobiinae Subfam. Nov. (Nematoda, Oxyurida) Pinworm Parasites of Primates and Rodents" (1995). Faculty Publications from the Harold W. Manter Laboratory of Parasitology. 61.

https://digitalcommons.unl.edu/parasitologyfacpubs/61

This Article is brought to you for free and open access by the Parasitology, Harold W. Manter Laboratory of at DigitalCommons@University of Nebraska - Lincoln. It has been accepted for inclusion in Faculty Publications from the Harold W. Manter Laboratory of Parasitology by an authorized administrator of DigitalCommons@University of Nebraska - Lincoln. 


\title{
The Enterobiinae Subfam. Nov. (Nematoda, Oxyurida) Pinworm Parasites of Primates and Rodents
}

\author{
J. P. HUGOT, ${ }^{*} \uparrow$ S. L. GARDNER $\ddagger$ and S. MORAND $\S$ \\ * Musém national d'Histoire Naturelle, Paris Laboratoire de Biologie Parasitaire- \\ Protistologie-Helminthologie, URA no. 114, 61, rue Buffon, 75231 Paris cedex 05, France \\ $\ddagger$ Harold $W$. Manter Laboratory of Parasitology, The University of Nebraska State \\ Museum, W-529, Nebraska Hall, 68588-0514, Lincoln, Nebraska, U.S.A. \\ $\S$ Université de Perpignan, Laboratoire de Biologie Animale, URA No. 698, 66025 , \\ Perpignan, France
}

(Received 29 May 1995; accepted 20 September 1995)

\begin{abstract}
Hugot J. P., Gardner S. L. \& Morand S. 1996. The Enterobiinae subfam. nov. (Nematoda, Oxyurida) pinworm parasites of primates and rodents. International Journal for Parasitology 26: 147-159. Recent redescriptions of most members of the Oxyuridae Cobbold, 1864 parasitic in primates revealed that they share following derived characters: sexual dimorphism of lateral alae (single-crested in the males, doublecrested in the females); in males a second pair of genital papillae always surrounded by strongly cuticularized rings; in females, uterine tube divided into 2 parts by a cellular wall forming a diaphragm. These characters are interpreted as synapomorphies, providing evidence that these taxa represent a monophyletic group, and we propose to classify them in a new subfamily of the Oxyuridae: the Enterobiinae subfam. nov. The Enterobiinae as recognized herein occurs in both Old World and New World Primates and rodents of the family Sciuridae (tribe Sciurini in the Holarctic region and tribe Xerini in the Ethiopian region). The new subfamily includes the following genera: Enterobius Leach, 1853; Colobenterobius Quentin, Betterton \& Krishnasamy, 1979; Rodentoxyuris Quentin \& Tenora 1974; Xeroxyuris Hugot, 1995; Lemuricola Chabaud \& Petter, 1959; Protenterobius Inglis, 1961; Madoxyuris Chabaud, Brygoo \& Petter, 1965; Trypanoxyuris Vevers, 1923; Hapaloxyuris Inglis \& Cosgrove, 1965 and Paraoxyuronema Artigas, 1936. The genus Paraoxyuronema is revalidated as a subgenus of Trypanoxyuris due to its very specialized buccal structures. This genus groups all pinworm nematodes specific for primates of the family Atelidae, including: $P$. brachytelesi Artigas, 1937 occurring in Brachyteles arachnoides; $P$. atelis (Cameron, 1929) occurring in Ateles spp., and $P$. duplicidens (Buckley, 1931) and $P$. lagothricis (Buckley, 1931), which are parasites of Lagothrix spp. Inglisoxyuris inglisi Chabaud, Petter \& Golvan, 1961, included in the monospecific genus Inglisoxyuris and previously classified as a subgenus of the Lemuricola, does not share the characters of the new subfamily and, until its precise classification can be considered with more information, it is proposed to refer to this species as an Oxyuridae sensu lato. A diagnosis and a key of the genera included in the new subfamily are given.
\end{abstract}

Key words: Enterobiinae subfam. nov.; primates; oxyurida; nematoda; Buckleyenterobius; Colobenterobius; Enterobius; Hapaloxyuris; Inglisoxyuris inglisi; Lemuricola; Madoxyuris; Oxyuronema; Paraoxyuronema brachytelesi; P. atelis; P. duplicidens; P. lagothricis; Protenterobius; Rodentoxyuris; Trypanoxyuris; Xeroxyuris.

\section{INTRODUCTION}

Pinworm occur in most families and genera of the order Primates, including: Colobidae, Cercopithe-

$\dagger$ To whom correspondence should be addressed.

E-mail: hugot@mnhn.fr. cidae, Pongidae, Hominidae, Callitrichidae, Atelidae, Cebidae, Lemuridae, Cheirogaleidae, Daubentoniidae and Lorisidae. Cameron (1929) was first to speculate on the possible coevolutionary relationships among families or groups of primates and their oxyurid parasites. His hypothesis was based on the 
pattern of distribution of the parasites in various taxa of their hosts: he observed that each species of parasitic nematode occurred in a specific group or species of host. Recent redescriptions revealed that most members of the Oxyuridae Cobbold, 1864 parasitic in primates share derived characters which allow us to interpret the whole as a monophyletic group. Therefore we propose to classify them as a new subfamily, the Enterobiinae subfam. nov.

\section{GENERA CLASSIFIED IN THE ENTEROBIINAE SUBFAM. NOV.}

The new subfamily groups together all the Oxyuridae parasitic in primates and squirrels and classified by Petter \& Quentin (1976) in the genera Enterobius Leach, 1853, Trypanoxyuris Vevers, 1923 and Lemuricola Chabaud \& Petter, 1959, except Inglisoxyuris inglisi Chabaud, Petter \& Golvan, 1961 a parasite of Lepilemur ruficaudatus Grandidier. This last species, previously classified as a subgenus in Lemuricola, does not share the derived characters described herein. Until the precise classification of this monospecific genus can be considered with more information, we prefer placing this species in the family Oxyuridae sensu lato. The identification of the host follows Ellerman, Morrison-Scott \& Hayman (1953), Meester \& Setzer (1971) and Honacki, Kinman \& Koeppl (1982). For the subdivision of Platyrrhini in three families, Atelidae, Cebidae and Callitrichidae, we refer to Hoffstetter (1982).

Enterobius (Enterobius) Leach, 1853

Synonyms. [Oxyurias Stiles \& Hassal, 1905] [Fusarella Seurat, 1916] [Lumbriculus Blanchard, 1889].

Type species. Enterobius vermicularis (L., 1758) parasite of Homo sapiens L.

Distribution. Ceropithecidae, Pongidae and Hominidae in their whole range.

Comments. For redescription of Enterobius spp. parasitic in Hominidae and Pongidae see Hugot (1983) Hugot \& Tourte-Schaeffer (1985) and Hugot (1993).

Enterobius (Colobenterobius) Quentin, Betterton \& Krishnasamy, 1979

Type species. Colobenterobius longispiculum Quentin et al., 1979 parasite of Presbytis obscura (Reid) in Malaysia.
Distribution. Colobidae (Ethiopian and Oriental regions).

Comments. See Hugot (1987a,b) for redescription of Colobenterobius spp.

Trypanoxyuris (Trypanoxyuris) Vevers, 1923

Type species. Trypanoxyuris trypanuris Vevers, 1923 from Pithecia monachus E. Geoffroy in British Guyana.

Distribution. Cebidae (Neotropical region).

Comments. For redescription of Trypanoxyuris spp. see Hugot (1985), Hugot \& Vaucher (1985) and Hugot, Morand \& Guerrero (1994).

Trypanoxyuris (Hapaloxyuris) Inglis \& Cosgrove, 1965

Type species. Hapaloxyuris tamarini (Inglis \& Dunn, 1964) from Saguinus nigricollis (Spix) in Peru. Distribution. Callitrichidae in Neotropical region.

Comments. For redescription of Hapaloxyuris spp. see Hugot (1984b).

Trypanoxyuris (Paraoxyuronema) Artigas, 1936

Synonyms. [Buckleyenterobius, Sandosham, 1950] [Odontorobius Skrjabin \& Schikhobalova, 1951].

Type species. Paraoxyuronema brachytelesi Artigas, 1936 from Brachyteles arachnoides (E. Geoffroy) in Brazil.

Other species. P. atelis (Cameron, 1929) parasite of Ateles spp., P. duplicidens (Buckley, 1931) and $P$. lagothricis (Buckley, 1931) parasites of Lagothrix spp.

Distribution: Atelidae (Neotropical region).

Comments. The first species to be described from a monkey of the family Atelidae was Trypanoxyuris atelis by Cameron (1929) who placed it in the genus Enterobius. Buckley (1931) provided the first complete description of the buccal structures characteristic of this group (see herein after in section on "characters" and Fig. 1L-O) and he stated that "... for there appears to be ample justification, on the basis of structural differences, for the erection of a new genus for these two species and E. atelis", but did not propose a new name. Kreis (1932) described as Oxyuronema atelophora, oxyurid-like nematodes collected in an Ateles geoffroyi Kuhl which died in

Fig. 1. Different patterns of buccal structures in the Enterobiinae subfam. nov. Plesiomorphic pattern (head in apical view) in: A, Xeroxyuris parallela (Linstow, 1908), female; B, Lemuricola microcebi Hugot, Gardner \& Morand, 1995, female; C, Enterobius bipapilatus Gedoelst, 1916, male. Derived patterns, exhibiting sexual dimorphism (head in apical view) in: Trypanoxyuris trypanuris Vevers, 1923, D, female, E, male; Hapaloxyuris tamarini (Inglis \& Dunn, 1964), F, female, G, male; Trypanoxyuris microon (Linstow, 1907), J, female, K, male. Differentiated superstructures on teeth in: Colobenterobius paraguerezae Hugot, 1987a, H, head in apical view, I, optical section in ventral view. Example of derived pattern encountered in Paraoxyuronema spp. [several views of the head of the female of $P$. atelis (Cameron, 1929)]: L, apical view, $\mathbf{M}$, idem, cross-section, $\mathbf{N}$, frontal section in a ventral view and $\mathrm{O}$, saggital section in a right lateral view, Not to same scale. 
The Enterobiinae subfam. nov.

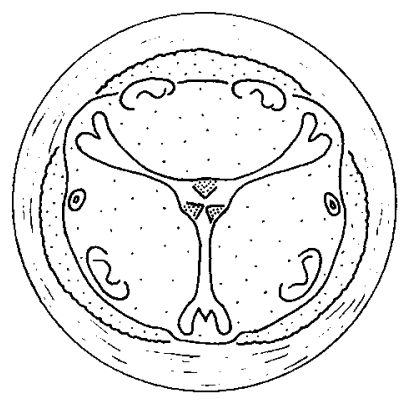

A
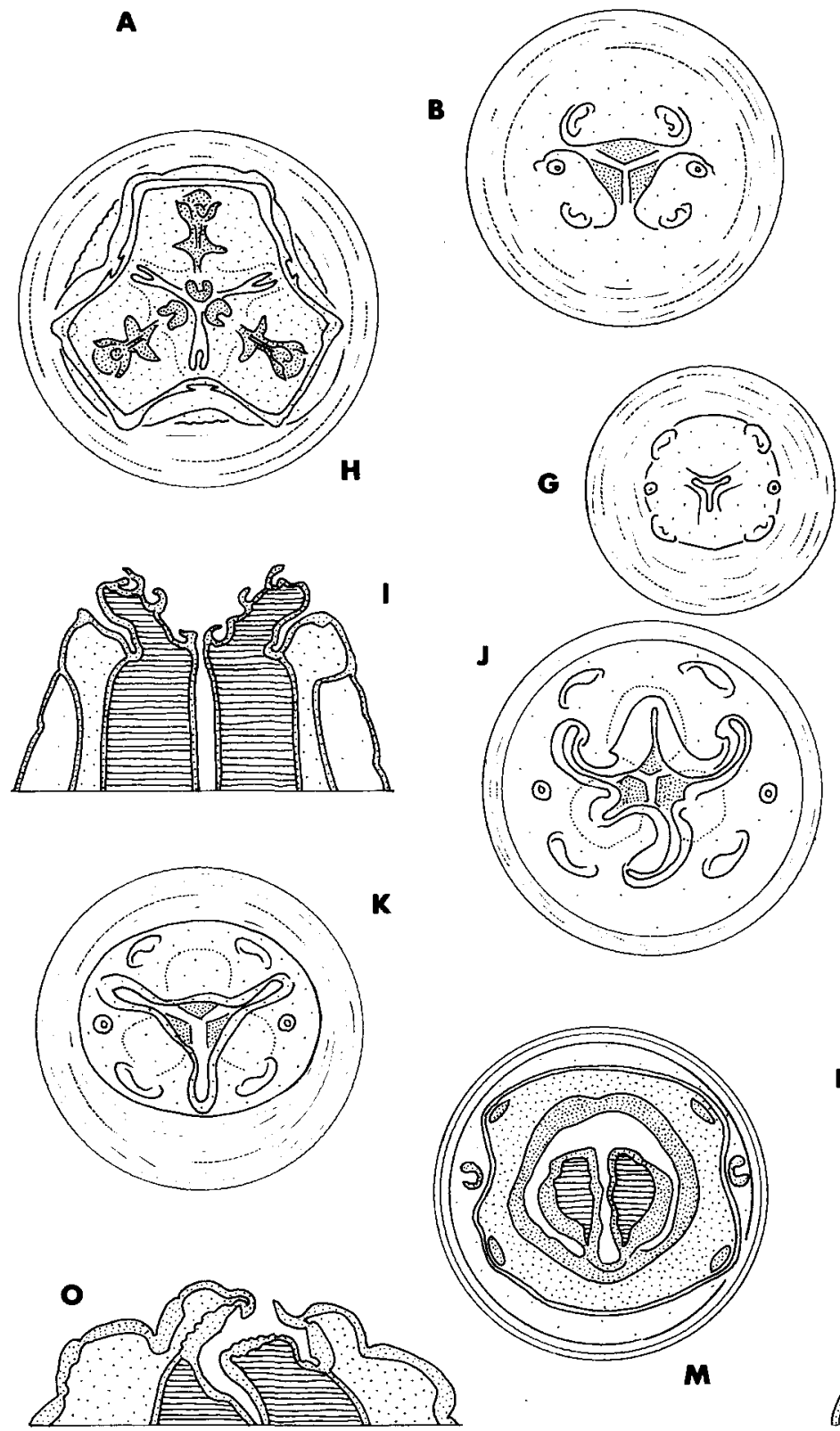
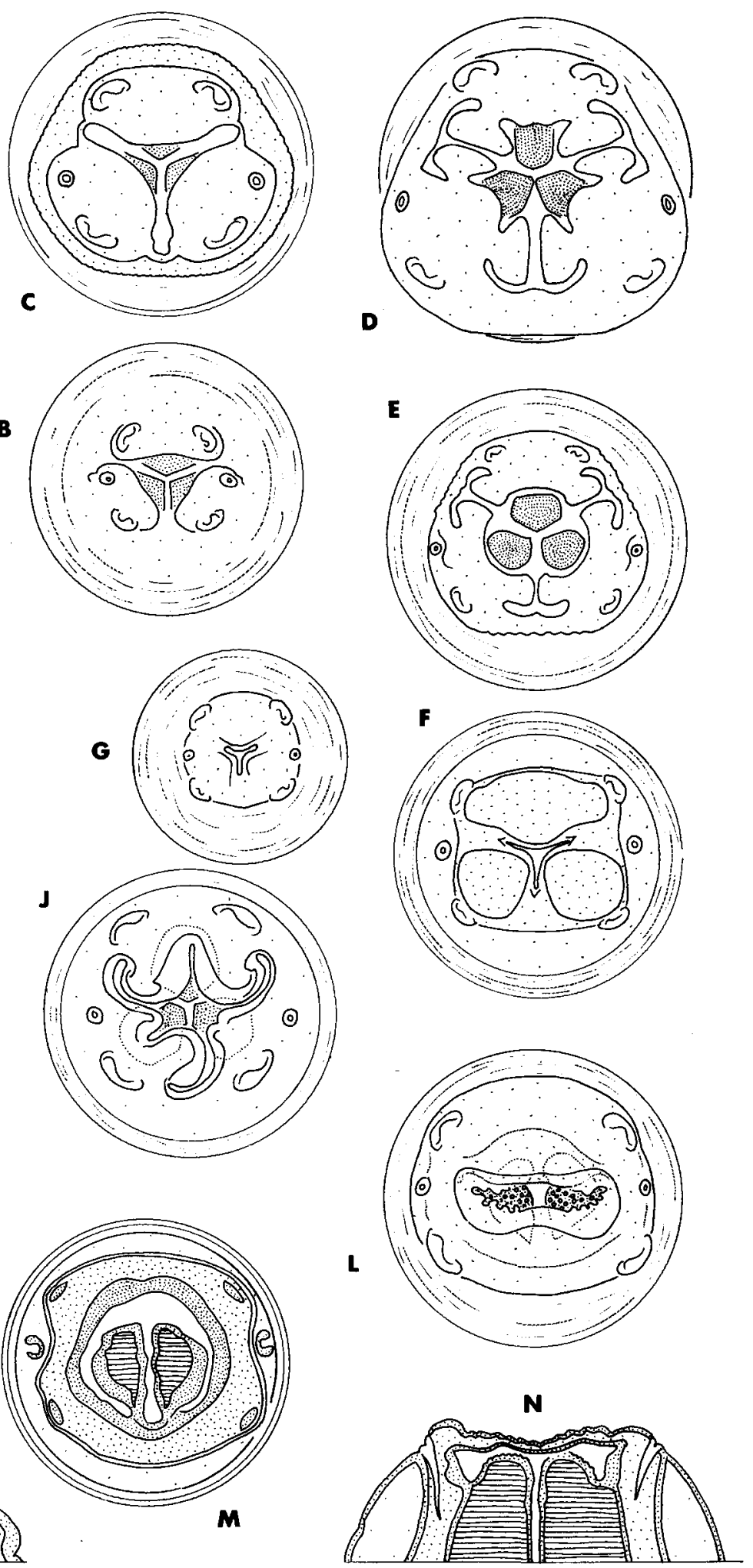

Fig. 1. 
captivity in the Parasitology Laboratory at Tulane University (Louisiana). Artigas (1936) described Paraoxyuronema brachytelesi from a specimen of Brachyteles arachnoides (E. Geoffroy) from Brazil. Sandosham (1950) and Dollfus \& Chabaud (1955), both concluded that the specimens described by Kreis (1932) refer in part to the species described by Cameron (1929) and the other specimens probably representing an undescribed species. In addition, Sandosham (1950), overlooking the work by Artigas (1936) proposed Buckleyenterobius as a new generic name for the parasites from primates of the family Atelidae.

The structural arrangement of the buccal cavity of oxyurids occurring only in primates of the family Atelidae is highly derived and is not present in Oxyurida from other host-groups. Even considered alone, these characters provide sufficient justification to classify these nematodes in a different taxon. The genus Paraoxyuronema was considered of doubtful validity by Inglis \& Cosgrove (1965), but the original description by Artigas (1936) allows the recognition of the characteristic structure of the female genital that unites the subfamily: "Apparelho genital feminino constituido por dos tubos confluentes e oppostos. Vagina longa e musculosa, dirigida para trás e continuando-se num ovejector com duas porcões nitidas". No drawing of the apical view of the head was given, but the description of the buccal aperture: "Bocca extramente reduzida ... Tem-se a impressão de que o esophago se abre directamente na extremidade anterior, cercado apenas pela dobra da expansão cephalica ... "appears identical to the buccal cavity and associated structures observed in the related species described by Cameron (1929) and Buckley (1931). Thus Paraoxyuronema is the first generic name given to a clearly identified parasite of the group. Herein we reinstate the name Paraoxyuronema as a subgenus of Trypanoxyuris. Buckleyenterobius must be considered a junior synonym. The species described in Oxyuronema was probably described from type material containing a mixture of several species, and since it came from a host that died in captivity, the name must be considered a genus inquirendum.

\section{Trypanoxyuris (Rodentoxyuris) Quentin \& Tenora, 1974}

Type species. Rodentoxyuris sciuri (Cameron, 1932) from Sciurus carolinensis Gmelin in Scotland. Distribution. Sciurini (Holarctic region).

Comments. Rodentoxyuris was first proposed as a subgenus for Lemuricola Chabaud \& Petter, 1959. For redescription of species of Rodentoxyuris and transfer of the generic name in Trypanoxyuris, see Hugot (1984a).
Lemuricola (Lemuricola) Chabaud \& Petter, 1959

Synonyms. [Biguetius Chabaud, Brygoo \& Petter, 1965].

Type species. Lemuricola contagiosus Chabaud \& Petter, 1959 from Cheirogaleus major (E. Geoffroy) in Madagascar.

Distribution. Cheirogaleidae and Microcebidae (Madagascar).

Comments. For redescription of Lemuricola spp. see Hugot, Morand \& Gardner (1995).

\section{Lemuricola (Protenterobius) Inglis, 1961}

Type species. Protenterobius nycticebi (Baylis, 1928) from Nycticebus coucang (Boddaert) in Borneo.

Distribution. Lorisidae (Eastern region).

Comments. Protenterobius was considered a subgenus in Lemuricola by Petter, Chabaud, Delavenay \& Brygoo (1972).

Lemuricola (Madoxyuris) Chabaud, Brygoo \& Petter, 1965)

Type species. Madoxyuris vauceli Chabaud, Brygoo \& Petter, 1965 from Lemur fulvus E. Geoffroy in Madagascar.

Distribution. Lemuridae (Madagascar).

\section{Xeroxyuris Hugot, 1995}

Type species. Xeroxyuris parallela (Linstow, 1908) from Xerus inauris (Zimmerman) in South Africa.

Distribution. Xerini (Ethiopian region).

Comments. The single species of this genus was first described in Oxyuris Rudolphi, 1803, later transferred to Enterobius. For the redescription see Hugot (1995).

\section{RESULTS}

\section{Description and interpretation of characters}

Cephalic and buccal structures. The most common arrangements of cephalic and buccal structures in the Enterobiinae subfam. nov. is shown in Fig. 1A-C. The buccal aperture is surrounded by 3 prominent lips, each partly covering a corresponding oesophageal tooth; the oesophageal teeth are triangular in shape, each with a small, sharp denticule; the 4 cephalic papillae are readily visible and the ventral papillae are often closer to the amphids. The arrangement of characters of this type is relatively common in other families of the Oxyurida, especially in members of the Syphaciinae Railliet, 1916 (see Hugot, 1988) and thus can be considered plesiomorphic. Figure 1 illustrates several derived patterns which can be observed in the Enterobiinae. In some taxa a more or less accentuated sexual dimorphism 
can be observed (Fig. 1D-G, J, K). The most derived buccal structures are encountered in the parasites specific for the Platyrrhini, and especially for the monkeys of the family Atelidae. In this last group the lips are modified and the buccal aperture changes from a triradiate to a bilateral symmetry; the dorsal oesophageal tooth curves dorsally and collapses with the internal side of the dorsal lip (Fig. 1L-O). This results in an hypertrophy of the ventral teeth which occupy most of the space in the buccal cavity. This character is sexually dimorphic: in males the dorsal tooth remains, while in females it is completely atrophied.

Lateral alae. In nematodes of the subfamily Enterobiinae, the lateral alae are bilaterally symmetrical and are composed of longitudinally directed expansions of the hypodermis and cuticle, running the length of the body. Sexual dimorphism of the lateral alae can generally be observed. In the males, the lateral alae consist of a single crest, originating between the anterior extremity and the oesophageal bulb, running the length of the body and ending anterior to the caudal bursa. In the females, the lateral alae are composed of 2 parallel crests originating laterally at about the level of the oesophagus and usually running the length of the body, ending close to the caudal extremity. The shape of the crests is species specific (Fig. 2). In some species, the lateral alae of the females differentiate into a cervical part, consisting of a single crest, and a posterior part with 2 parallel crests; a complete hiatus being observed between the 2 parts. In other species the alae are identical in both sex and composed of a single crest (Fig. 2F-H). This last pattern is generally associated with differentiated buccal features.

In nearly all the taxa known in the Oxyurida, the lateral alae are either absent in both sexes (Chitwood \& Chitwood, 1933; Adamson \& Buck, 1990), or present in males and absent in females (van Waerebeke, 1978), or present and almost identical in both sexes (Quentin, 1975; Hugot, 1988). Therefore the sexual dimorphism observed in most of the taxa discussed above (single-crests in the males, double- crests in the females) is interpreted as a synapomorphy. The absence of his character (lateral alae singlecrested in females) in only a few distantly related species, and often associated with differentiated buccal structures, is considered a reversal, or loss.

Genital characters of males. The ventral cuticle posterior to the excretory pore is always ornamented with an area rugosa represented by a split in the ventral region of each annulus. This basic arrangement is more complex in some species in which the ventral cuticle is inflated into a large round crest with corresponding hypertrophied muscle cells (Fig. 2A). There are always 4 pairs of caudal papillae, the first and the fourth are pedunculate and support the bursa, and the second and third pairs are sessile; flanking the longitudinally oriented slit-like opening of the cloaca. The tubes of the phasmids begin at the base of the peduncles of the fourth pair of caudal papillae. Each papilla of the second pair is always surrounded by strong ring-shaped thickening (Fig. 3B-E) and we interpret this character as a synapomorphy. This ornamentation may also encircle the third pair of genital papillae (Fig. 3A). In some species these 4 rings and the cuticularized posterior lip of the doaca are connected with a small square cuticularized sheet, sometimes bearing 2 ventral extensions that is species specific (Fig. 3F-J). In other species the thickening of the cuticle correspondence to these rings extends laterally and ornaments the lateral part of the body; the shape of these structures also being species specific (Fig. 3K-M). The single spicule of these nematodes are highly variable in size and shape, with the manubrium always with a cuticularized mass to which the musculature of the spicule is attached (Fig. 2I-L).

Genital characters of females. The vulva is followed by a muscular vagina and uterine tube divided into 2 parts by a cellular wall $(\mathrm{cw})$, forming a diaphragm. Between the muscular vagina and the cellular wall an accumulation of cells occurs. In addition, no spermatheca can be observed at the level of the oviducts of these species and, when dissecting the genital tract of numerous females, we could observe

\section{Caption for Figure 2}

Fig. 2. Different patterns of lateral alae in the Enterobiinae subfam. nov. represented on cross-sections (the left side of each figure shows the male pattern, the right side the female pattern): A, Lemuricola microcebi Hugot, Gardner \& Morand, 1995; B, Xeroxyuris parallela (Linstow, 1908); C, Trypanoxyuris satanas Hugot, 1985; D, T. croizati Hugot, Morand \& Guerrero, 1994; E, Trypanoxyuris minutus (Schneider, 1866); F, Paraoxyuronema atelis (Cameron, 1929); G, Enterobius gregorii Hugot, 1985; H, Colobenterobius paraguerezae Hugot, 1987a. Different patterns of spicule in a left lateral view: I, X. parallela; J, E. vermicularis (L., 1758); K, Rodentoxyuris bicristata Hugot, 1984a; L, Colobenterobius colobis Yin, 1973. Different patterns of eggs: M and N, T. satanas; O, Hapaloxyuris tamarini (Inglis \& Dunn, 1964); P, E. vermicularis. Not to same scale. 

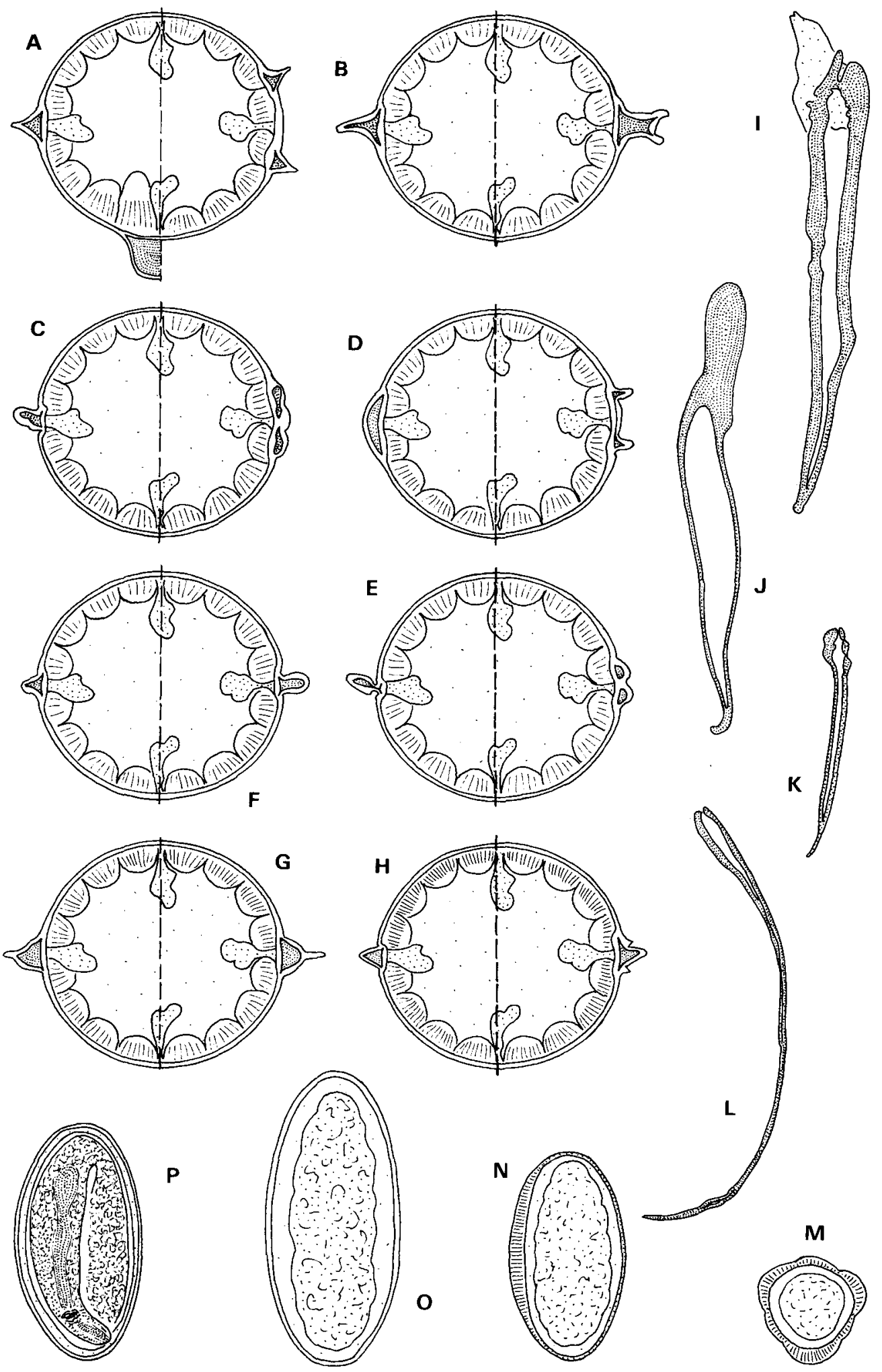

Fig. 2. Caption on page 151. 

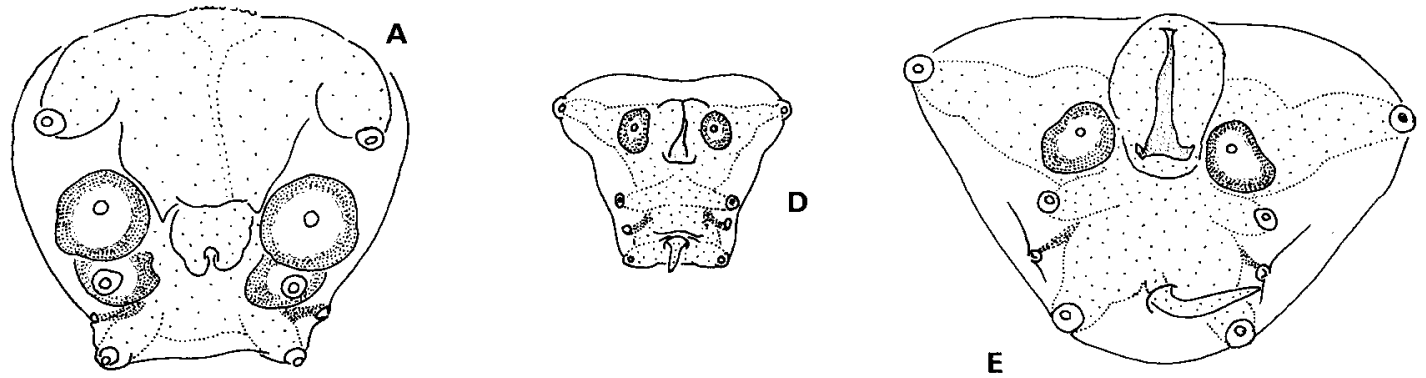

C
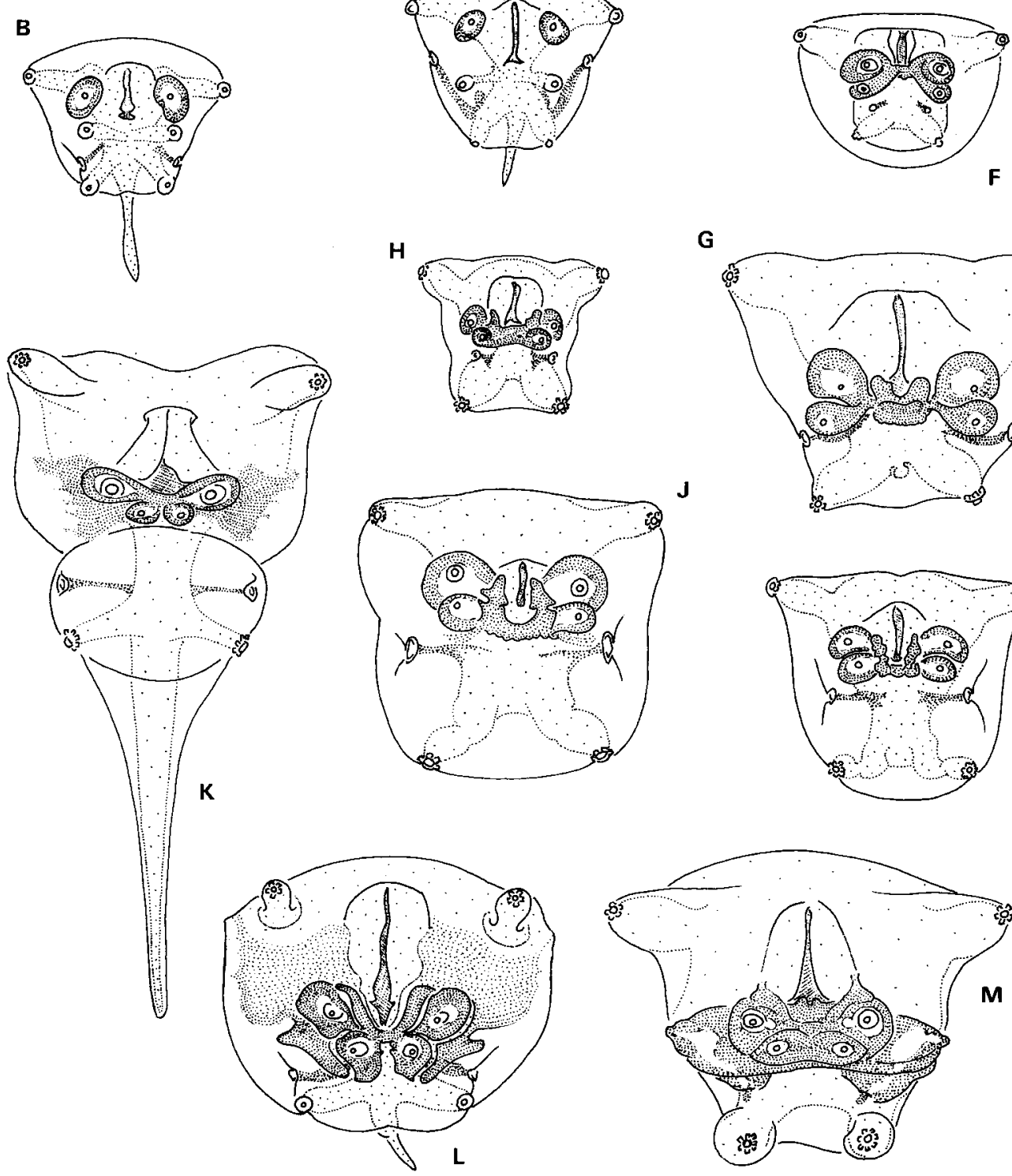

$\mathbf{G}$
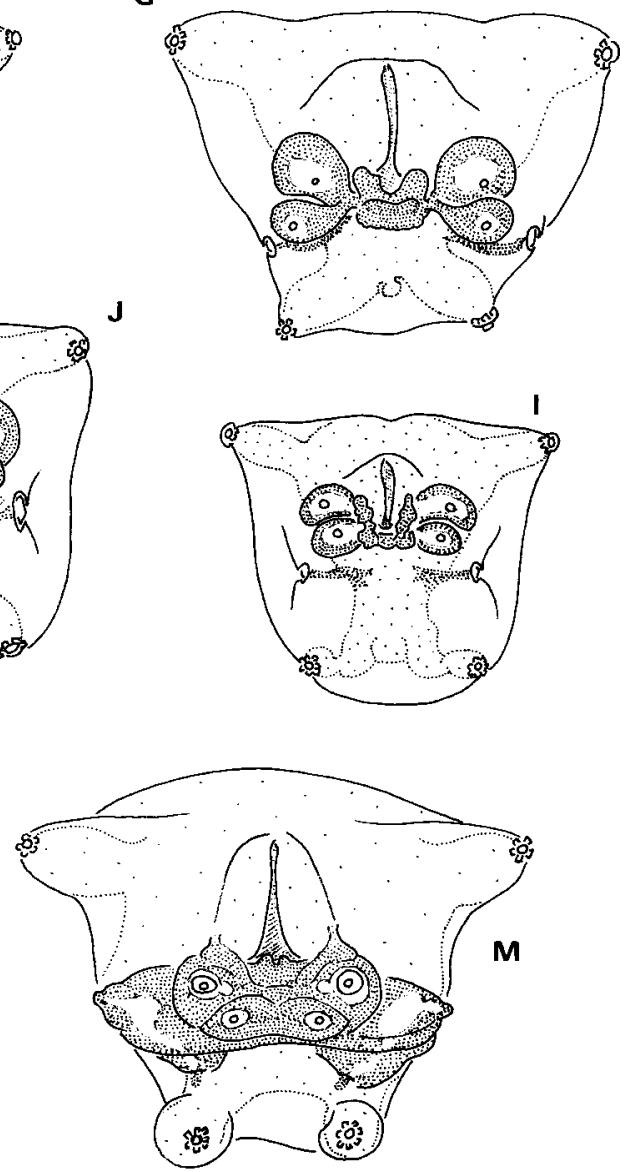

Fig. 3. Different patterns of caudal bursa in the Enterobiinae subfam. nov.: A, Xeroxyuris parallela (Linstow, 1908); B, Rodentoxyuris bicristata Hugot, 1984a; C, Hapaloxyuris oedipi Inglis \& Cosgrove, 1965; D, Trypanoxyuris sceleratus (Travassos, 1925); E, T. croizati Hugot, Morand \& Guerrero, 1994; F, Colobenterobius zakiri Siddiqi \& Mirza, 1954; G, C. colobis Linstow, 1908; H, Enterobius anthropopitheci Gedoelst, 1916; I, E. gregorii Hugot, 1983; J, E. vermicularis (L., 1758); K, Lemuricola microcebi Hugot, Morand \& Gardner, 1995; 1, Protenterobius nycticebi (Baylis, 1928); M, Madoxyuris lemuris (Baer, 1935). Not to same scale. 
that one branch of the oviduct runs parallel and very close to the anterior part of the uterine tube (Fig. 4F). The posterior part of the uterine tube leads to 2 uterine branches which are generally amphidelphic (with the single exception of the arrangement in Xeroxyuris Hugot, 1995).

In the Oxyurida, males usually mate with females just emerging from the last moult. In such females the vulva, vagina, and uterine tube are fully developed, but the uteri, oviducts and ovaries remain undifferentiated. Spermatozoa are first stored in the uterine tube and later migrate through the uteri to the spermathecae after the paired segments of the genital tract become developed (Maupas \& Seurat, 1916; Seurat, 1916, 1920; Hugot, 1982). In the genital tract here described, no spermatheca was observed, nor were spermatozoa observed in the oviducts; we therefore hypothesize that the accumulation of cells in the uterine tube are sperms that have been stopped by the differentiated cells of the oviducts (cellular wall or diaphragm). We interpret this particular disposition of the genital tract as an adaptation to the haplodiploid mode of reproduction first described in the oxyurids by Adamson (1981). Adamson (1984b) also showed that several species in different families share this character and he speculated that haplodiploidy is a generalized characteristic of the Oxyurida. As sperm were never observed in the oviducts, we hypothesize that successful fertilization of ova probably occurs by passage of sperm (via diapedesis) through the walls of both the uterine tube and the oviduct which is juxtaposed. In this oviduct the ova are fertilized, and develop into diploid, female nematodes, and in the oviduct that is not in close proximity (i.e. not juxtapositioned) to the uterine tube, the ova do not become fertilized, thus producing unfertilized haploid, male nematodes. A similar asymmetry of the genital tract, with each branch producing either diploid or haploid eggs has been described in other groups of the Oxyurida (Adamson, 1984a; Hugot, Morand \& van Waerebeke, 1991). Figure 4 gives several examples of this character which is interpreted as a synapomorphy.

Eggs. Thin-shelled, oval, symmetrical or asymmetrical, embryonated or non-embryonated; shell surface finely granulated; opercule present or absent (Fig. 2M-P).

\section{Enterobiinae subfam. nov.}

The sexual dimorphism observed in most of the taxa enumerated above (lateral alae single-crested in the males, double-crested in the females), the presence in the males of a second pair of genital papillae always surrounded by strongly cuticularized rings and the presence in the females of a uterine tube divided into 2 parts by a cellular wall forming a diaphragm, are considered synapomorphies. We therefore propose to classify these taxa in a new subfamily, the Enterobiinae named from its type genus: Enterobius Leach, 1853.

\section{Diagnosis.}

Male. Lateral alae always single-crested. Four pairs of caudal papillae: first and fourth stout pedunculated supporting bursa; 2 sessile intermediate pair flanking cloacal opening; second pair adanal and constantly surrounded by strongly cuticularized rings; phasmidian tubes beginning at base of peduncles of fourth caudal papillae; spicule variable in size and shape; manubrium thickened, serving as the insertion of the musculature of the spicule.

Female. lateral alae generally double-crested (except Enterobius vermicularis, E. gregorii Hugot, 1983, and the genera Paraoxyuronema and Colobenterobius). Vulva situated in first third of the body; ovejector leading posteriorly, with 3 well-defined segments consisting of (i) vagina with thick muscular wall, followed by a uterine tube constituted of (ii) an anterior portion with thin muscular wall and low columnar epithelial cells, separated from a posterior portion (iii) by a cellular diaphragm; the third portion having the same histological features than the uteri and emptying into them nearby at the middle of the body; uteri amphidelphic (except in Xeroxyuris); 2 ovaries emptying through oviducts into uteri without seminal receptacle; sperm accumulated in the anterior portion of uterine tube; 1 oviduct branch always parallel and very close to the anterior part of the uterine tube.

Distribution. The Enterobiinae occur in Old World and New World Primates, Sciurids of the tribe Sciurini in the Holarctic region and Sciurids of the tribe Xerini in the Ethiopian region.

Key to the genera of the Enterobiinae subfam. nov.

1-(8) Second pair of genital papillae in males surrounded by 2 strongly cuticularized rings, tail

Fig. 4. Different patterns of vulva, muscular vagina and uterine tube divided into 2 parts by cellular wall, forming a diaphragm (cw), in the Enterobiinae subfam. nov.: Enterobius vermicularis (L., 1758), A, lateral view, B, detail of the cellular wall on a cross-section of the body; C; Rodentoxyuris bicristata Hugot, 1984a; D, Trypanoxyuris sceleratus (Travassos,

1925); E; Colobenterobius zakiri Siddiqi \& Mirza, 1954; F, Xeroxyuris parallela (Linstow, 1908), Not to same scale. 

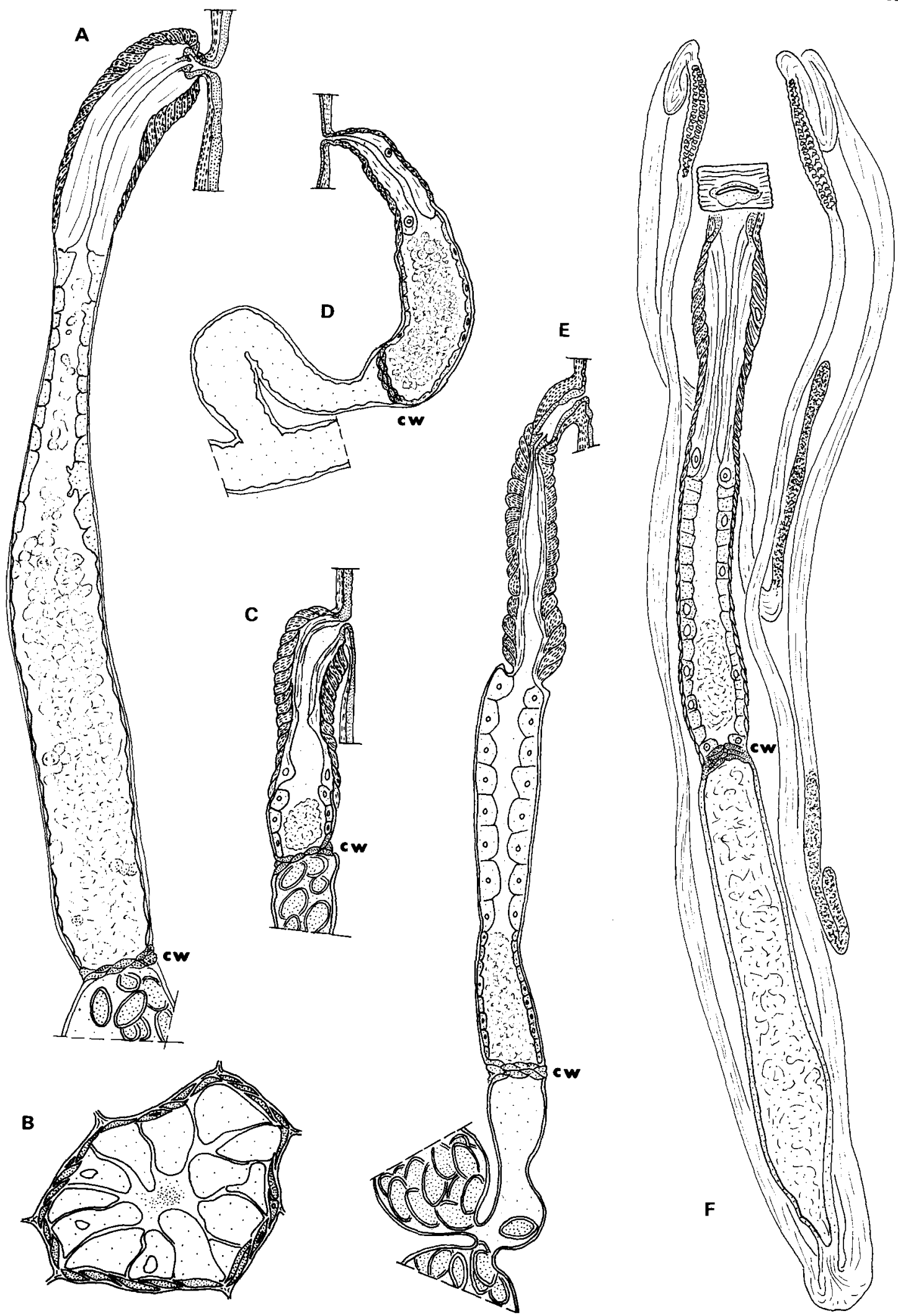

Fig. 4. 
appendix always present (Fig. 3B-E). In females distance of vulva to cellular diaphragm $\leqslant$ to distance of cellular diaphragm to opening of the uterus (Fig. 4D). Parasites of Platyrrhini and Sciurini.

Trypanoxyuris Vevers, 1923.

2-(3) Ratio of oesophagus length/bulb length $<3$ in males and females. Area rugosa with a ventral rounded crest extending along the posterior half of the mid-ventral line. In females, dorsal lip occupying the dorsal half of the head (Fig. 1F). Parasite of Callitrichidae.

Trypanoxyuris (Hapaloxyuris) Inglis \& Cosgrove, 1965.

3-(2) Ratio of oesophagus length/bulb length $>3$ in males, $>4$ in females. Area rugosa without ventral crest.

4-(5) Ratio of oesophagus length/bulb length $<3,8$ in males. No sexual dimorphism in buccal structure. Parasites of Sciurini.

Trypanoxyuris (Rodentoxyuris) Quentin \& Tenora, 1974.

5-(4) Ratio oesophagus length/bulb length $>4,3$ males. Sexual dimorphism always present in buccal structure. Parasite of Cebidae and Atelidae.

6-(7) Lateral alae in females double crested. Three lips (Fig. 4D, E, J, K). Parasite of Cebidae.

\section{Trypanoxyuris (Trypanoxyuris)}

7-(6) Lateral alae in females with simple crests. Two lips (Fig. $4 \mathrm{~L}-\mathrm{O}$ ). Parasite of Atelidae.

Trypanoxyuris (Paraoxyuronema) Artigas, 1936.

8 (1) Second and third pairs of genital papillae in males surrounded by 4 strongly cuticularized rings, tail appendix present, atrophied or absent. In females length vulva to cellular diaphragm $>$ to length cellular diaphragm to opening of the uterus (Figs 4A, E, F). Parasites of Catarrhini, Strepsirrhini and Xerini.

9 (10) Genital tract prodelphic (Fig. 4F). Cloacal opening covered by a flap, extremity of spicular pouch protruding from cloaca, annular gubernaculum present, second and third pairs of genital papillae in males surrounded by 4 relatively weakly cuticularized rings not connected behind posterior end of cloacal aperture, tail appendix absent (Fig. 3A). Parasite of Xerini.

Xeroxyuris Hugot, 1995.
10-(9) Genital tract amphidelphic. Cloacal opening covered by a longitudinal slit, extremity of the spicular pouch not protruding from the cloaca, annular gubernaculum absent, second and third pairs of genital papillae in males surrounded by 4 strongly cuticularized rings connected behind posterior end of cloacal aperture. Parasites of Catarrhini and Strepsirrhini.

$11-(14)$ Thickening of cuticle corresponding to cuticularized rings not extending laterally, caudal appendix atrophied or absent (Fig. 3F-J). Area rugosa without a ventral crest. Cuticular vagina directed posteriorly, well developed, with a valvular apparatus (Fig. 4A, E). Parasites of Catarrhini.

Enterobius Leach, 1853.

12-(13) Oesophageal teeth without superstructures. Cuticularized rings joined with a small square cuticularized sheet bearing 2 leaf-shaped ventral extensions (Fig. $3 \mathrm{H}-\mathrm{J}$ ). Parasites of Cercopithecidae, Pongidae Hominidae.

\section{Enterobius (Enterobius).}

13-(12) Oesophageal teeth with superstructures (Fig. 1H, I). Cuticularized rings connected with a small square cuticularized sheet without leaf-shaped ventral extensions (Fig. 3F, G). Parasites of Colobidae.

Enterobius (Colobenterobius) Quentin, Betteron, \& Krishnasamy, 1979.

14-(11) Thickening of cuticle corresponding to cuticularized rings extending laterally, caudal appendix present, atrophied or absent (Fig. 3KM). Area rugosa with a ventral crest extending along the posterior two-thirds of the midventral line (Fig. 2A). Cuticular vagina, directed anteriorly, short and without a valvular apparatus. Parasites of Strepsirrhini.

Lemuricola Chabaud \& Petter, 1959.

15-(18) Caudal appendix developed. Parasites of Lorisidae, Cheirogaleidae and Microcebidae.

16-(17) Tail appendix very long $>70 \%$ of total tail length. Parasites of Cheirogaleidae and Microcebidae.

\section{Lemuricola (Lemuricola).}

17-(16) Tail appendix very short $<20 \%$ of total tail length. Parasites of Lorisidae.

Lemuricola (Protenterobius) Inglis, 1961. 
18-(15) Tail appendix atrophied or absent. Parasites of Daubentoniidae and Lemuridae.

Lemuricola (Madoxyuris) Chabaud, Brygoo \& Petter, 1965.

\section{CONCLUSION}

The family Oxyuridae Cobbold, 1864 groups 3 subfamilies: the Oxyurinae, Syphaciinae Railliet, 1916 (sensu Hugot, 1988) and Enterobiinae subfam. nov. Establisment of the subfamilies Syphaciinae and Enterobiinae leaves 9 genera in the Oxyurinae (sensu Petter \& Quentin, 1976). Species of the general Austroxyuris, Paraustroxyuris, Marcropoxyuris and Potoroxyuris are parasites of Australian Marsupials; Auchenacantha occur only in species of Dermoptera, Citellina occurs solely in Sciuridae, Oxyuris in the Perissodactyla, Skrjabinema in the Artiodactyla, and Hoplodontophorus occurs only in the Hyracoidea. However, none of the characters currently used to define or subdivide the Oxyuridae can be shown to be useful in assessing the phylogenetic relationships among taxa in this group (i.e. the characters as presently defined, do not define the Oxyuridae as a monophyletic group).

Despite recent revision of the Systematics of several taxa in the Oxyurida, the current classification of the order as summarised by Adamson (1994) continues to reflect a host-based bias. This nonphylogenetic classification was first established when oxyurid parasites of vertebrates (the Oxyuroidea) were considered separately from those occurring in invertebrates (the Thelastomatoidea). Up to the present time, none of the taxa described at the superfamily or family level has been shown to be a monophyletic-natural group. The Oxyurida are unique among the parasitic forms in the Nematoda being the only group that was able to colonize and undergo a spectacular adaptive diversification in both invertebrates and vertebrates. With Adamson (1994) we agree that "The Oxyurida appears to represent a unique origin of parasitism ..." and that they first appeared and dispersed in arthropods, probably the Diplopoda. Pinworms representing several phylogenetic lineages and originally parasites of different groups of arthropods could have been independently "captured" (sensu Chabaud, 1965), becoming established in vertebrates. If this hypothesis is corroborated, most of the taxa at the superfamily and family levels will probably be recognized as paraphyletic, fitting with our current inability to prove the contrary. To make progress in this area, analyses must be conducted that recognize monophyletic groups by considering the order Oxyurida as a whole.
Acknowledgements - For assistance in reading drafts of this paper and helpful criticisms on earlier versions of the manuscript we thank Professor A. G. Chabaud. The work was supported in part by NATO collaborative research grant No. CRG 920612 to S. L. Gardner, J. P. Hugot, and S. Morand and by National Science Foundation Grant No. BSR-9024816 to S. L. Gardner.

\section{REFERENCES}

Adamson M. L. 1981. Studies on gametogenesis in Gyrinicola batrachiensis (Walton, 1929) (Oxyuroidea: Nematoda). Canadian Journal Of Zoology 59: 1368-1376.

Adamson M. L. 1984a. L'Haplodiploïdie des Oxyurida. Incidence de ce phénomène dans le cycle évolutif. Annals de Parasitologie Humaine et Comparée 59: 387-413.

Adamson M. L. 1984b. Anatomical adaptation to haplodiploidy in the oxyuroid (Nematoda). Desmicola skrjabini n. sp. from a Diplopod in Gabon. Annales de Parasitologie Humaine et Comparée 59: 95-99.

Adamson M. L. 1994. Evolutionary patterns in life histories of Oxyurida. International Journal for Parasitology 24: 1167-1177.

Adamson M. L. \& Buck A. 1990. Pinworms from water scavenger beetles (Coleoptera: Hydrophilidae) with a description of a new species, Zonathrix columbianus $\mathrm{sp} . \mathrm{n}$. (Oxyuridae: Pseudonymidae) from western Canada. Journal of the Helminthological Society, Washington 57: 21-25.

Artigas P. de Toledo 1936. Estudios helminthologicos. I. Paraoxyuronema brachytelesi g. n., sp. n., parasita de Brachyteles arachnoides (Geoff., 1806); Oxyuronemidae, fam. n. Memorios del Instituto de Butantan 10: 77-85.

Baylis H. A. 1928. Some further parasitic worms from Sarawak. Annals and Magazine of Natural History 1: 606-608

Blanchard R. 1889. Traité de Zoologie Médicale. Baillière et fils, Paris. I. viii +808 pp.

Buckley J. J. C. 1931. On two new species of Enterobius from the monkey Lagothrix humboldtii. Journal of Helminthology 9: 133-140.

Cameron T. W. 1929. The species of Enterobius Leach, in Primates. Journal of Helminthology 7: 161-182.

Cameron T. W. 1932. On a new species of Oxyuris from the grey squirrel in Scotland. Journal of Helminthology 10: 29-32.

Chabaud A. G. \& Petter A. J. 1959. Les Nématodes parasites de Lémuriens Malgaches. II. Un nouvel Oxyure: Lemuricola contagiosus. Mémoires de l'Institut Scientifique de Madagascar serie A, 13: 127-132.

Chabaud A. G. 1965. Spécificité parasitaire. I. Chez les Nématodes parasites de Vertébrés. In: Traite de Zoologie. Volume IV (2): Némathelminthes, (Edited by Grassé P. P.), pp. 548-557. Masson, Paris.

Chabaud A. G., Brygoo E. R. \& Petter A. J. 1965. Les Nématodes de Lémuriens Malgaches. VI. Description de six espèces nouvelles et conclusions générales. Annales de Parasitologie Humaine et Comparée 40: 181-214.

Chabaud A. G., Petter A. J. \& Golvan Y. 1961. Les Nématodes parasites de Lémuriens Malgaches. III. 
Collections récoltées par $\mathbf{M}$. et Mme Françis Petter. Annales de Parasitologie Humanine et Comparée 36: 113-126.

Chitwood B. G. \& Chitwood M. B. 1933. Nematodes parasitic in Philippine cockroaches. The Philippine Journal of Sciences 52: 381-396.

Cobbold T. S. 1864. Entozoa, an introduction to the study of Helminthology, more particularly to the internal parasites of man, p. 508.

Dollfus R. Ph \& Chabaud A. G. 1955. Cinq espèces de Nématodes chez un atéle [Ateles ater (G. Cuvier, 1823)], mort à la ménagerie du Muséum. Archives du Muséum National d'Histoire Naturelle 3: 27-40.

Ellerman J. R., Morrison-Scott T. C. S. \& Hayman R. W. 1953. Southern African Mammals. 1758 to 1951: a reclassification. British Museum (Natural History), London, 363 pp.

Hoffstetter R. 1982. Les Primates Simiiformes (= Anthropoidea). Compréhension, phylogénie histoire biogéographique. Annales de Paléontologie (Vertébrés et Invertébrés) 68: 241-290.

Honacki J. H., Kinman K. E. \& Koeppl J. W. 1982. Mammal Species of the world. A Taxonomic and Geographic Reference. Allen Press, Inc. and Ass. of Syst. Coll., Lawrance, Kansas, U.S.A. 694 pp.

Hugot J. P. 1982. Sur le genre Hilgertia (Oxyuridae, Nematoda) parasite de Rongeurs Ctenodactylidae. Bulletin du Muséum national d'Histoire naturelle, Paris, $4^{\circ}$ sér. 4: 419-431.

Hugot J. P. 1983. Enterobius gregorii (Oxyuridae, Nematoda), un nouveau parasite humain (Note préliminaire). Annales de Parasitologie Humaine et Comparée 58: 403-404.

Hugot J. P. 1984a. Sur le genre Trypaoxyuris (Oxyuridae, Nematoda). I. Parasites de Sciuridae: sous-genre Rodentoxyuris. Bulletin du Muséum National d'Histoire Naturelle, Série A, Zoologie 6: 711-720.

Hugot J. P. 1984b. Sur le genre Trypanoxyuris (Oxyuridae, Nematoda). II. Sous-genre Hapaloxyuris parasite de Primates Callitrichidae. Bulletin du Muséum National d'Histoire Naturelle, Série A, Zoologie 6: 1007-1019.

Hugot J. P. 1985. Sur le genre Trypanoxyuris (Oxyuridae, Nematoda). III. Sous-genre Trypanoxyuris parasite de Primates Cebidae et Atelidae. Bulletin du Muséum National d'Histoire Naturelle, Série A, Zoologie 7: 131-155.

Hugot J. P. 1987a. Sur le genre Enterobius: s.g. Colobenterobius. I. Oxyures parasites de Singes Colobinae en Région ethiopienne. Bulletin du Muséum National d'Histoire Naturelle, Série A, Zoologie 9: 341-352.

Hugot J. P. 1987b. Sur le genre Enterobius: s. g. Colobenterobius. II. Oxyures parasites de Singes Colobinac en région orientale. Bulletin du Muséum National d'Histoire Naturelle, Série A, Zoologie 9: 799-813.

Hugot J. P. 1988. Les nématodes Syphaciinae parasites de Rongeurs et de Lagomorphes. Taxonomie. Zoogéographie, Evolution. Mémoires du Muséum national d'Histoire Naturelle, Paris, Série A, Zoologie 141: 1-153.

Hugot J. P. 1993. Redescription of Enterobius anthropopitheci (Nematoda, Oxyurida), parasite of the chim- panzees. Systematic Parasitology 26: 201-207.

Hugot J. P. 1995. Redescription of Xeroxyuris parallela (Linstow, 1907) n. gen., n. cb., parasite of Xerus inauris. Parasite 3: (in press).

Hugot J. P., Morand S. \& Gardner S. L. 1995. Morphology and Morphometrics of three oxyurids parasitic in Primates. Description of Lemuricola microcebi $\mathrm{n}$. $\mathrm{sp}$. International Journal for Parasitology 25: 1065-1075.

Hugot J. P., Morand S. \& Guerrero R. 1994. Trypanoxyuris croizati $\mathrm{n}$. sp. and $T$. callicebi, two vicariant forms parasite of Callicebus spp. (Primate, Cebidae). Systematic Parasitology 27: 35-43.

Hugot J. P., Morand S. \& van Waerebeke D. 1991. On genus Desmicola (Nematoda, Thelastomatidae) with description of two new species. Research and Review in Parasitology 51: 61-70.

Hugot J. P. \& Tourte-Schaffer C. 1985. Etude morphologique des deux oxyures parasites de l'Homme: Enterobius vermicularis et E. gregorii. Annales de Parasitologie Humaine et Comparée 60: 57-64.

Hugot J. P. \& Vaucher C. 1985. Sur le genre Trypanoxyuris (Oxyuridae, Nematoda). IV. Sous-genre Trypanoxyuris parasite de Primates Cebidae et Atelidae (suite). Etude morphologique de Trypanoxyuris callicebi $\mathrm{n}$. sp. Bulletin du Muséum National d'Histoire Naturelle, Série A, Zoologie 7: 633-636.

Inglis W. G. 1961. The oxyurids parasites (Nematoda) of Primates. Proceedings of the Zoological Society of London 136: 103-122.

Inglis W. G. \& Cosgrove G. E. 1965. The pin-worms parasites (Nematoda: Oxyuridae) of the Hapalidae (Mammalia: Primates). Parasitology 55: 731-737.

Inglis W. G. \& Dunn F. L. 1964. Some Oxyurids from Neotropical Primates. Zeitschrift für ParasitenKunde 24: 83-87.

Kreis H. A. 1932. A new pathogenic nematode of the Oxyuroidea, Oxyuronema atelophora n. sp. in the red monkey, Ateles geoffroyi. Journal of Parasitology 18: 295-302.

Leach (ms. in W. Baird, 1853). Catalogue of the species of entozoa, or intestinal worms, contained in the collection of the British Museum, 132 pp.

Linstow O. F. B. 1908. Zoologische und Anthropologische Ergebisse einer Forschungsreise im Westlichen und Zentralen Südafrika ausgefürhrt in den Jahren 1903 1905. II. Helminthes. Nematoden und Acanthocephalen. Denkschriften Medizin-naturwissenschaftliche Gesellschaft Jena 13: 19-28.

Maupas E. \& Seurat L. G. 1916. Sur les mécanisms de l'accouplement chez les Nématodes. Comptes rendus des séances de la Societé Biologique de Paris 79: 607-611.

Meester J. \& Setzer H. W. 1971. A Handbook of Africa's Mammals. Part 3. Order Primates. Smithsonian Institution Ed.

Petter A. J., Chabaud A. G., Delavenay R. \& Brygoo E. R. 1972. Une nouvelle espèce de Nématode du genre Lemuricola, parasite de Daubentonia madagascariensis Gmelin, et considérations sur le genre Lemuricola. Annales de Parasitologie Humaine et Comparée 47: 391-398. 
Petter A. J. \& Quentin J. C. 1976. Keys to the genera of the Oxyuroidea. In: CIH Keys to the Nematodes parasites of Vertebrates. $N^{\circ} 4$ (Edited by Anderson R. C., Chabaud A. G. \& Willmott S.), pp. 1-30. Commonwealth Agricultural Bureaux, Farnham Royal, Slough, U.K.

Quentin J. C., Betterton C. \& Krishnasamy M. 1979. Oxyures nouveaux ou peu connus, parasites de Primates, de Rongeurs et de Dermoptères en Malaisie. Création du sous-genre Colobenterobius $\mathrm{n}$. subgen. Bulletin $d u$ Muséum National d'Histoire Naturelle, Série $A$, Zoologie 1: 1031-1050.

Quentin J. C. \& Tenora F. 1974. Morphologie et position sytématique de Lemuricola (Rodentoxyuris) sciuri (Cameron, 1932) nov. comb. nov. subgen., et Syphacia (Syphatineria) funambuli Johnson, 1967. Oxyures (Nematoda) parasites de Rongeurs Sciuridés. Bulletin du Muséum National d'Histoire Naturelle, $3^{\circ}$ série, Zoologie 178: 1525-1535.

Railliet A. 1916. Nématodes parasites de Rongeurs. Recueil de Médecine Véterinaire de l'Ecole d'Alfort 92: 517-521.

Rudolphi C. A. 1803. Neue Beobachtungen über die Eingeweidewürmer. Archiv für Zoologie und Zootomie, Braunschweig 3: 1-32.

Sandosham A. A. 1950. On Enterobius vermicularis (Lin- naeus, 1758) and some related species from Primates and Rodents. Journal of Helminthology 24: 171-204.

Seurat L. G. 1916. Sur les Oxyures de Mammifères. Comptes-Rendus de la Société Biologique de Paris 79: 64-68.

Seurat L. G. 1920. Histoire naturelle des Nématodes de la Berbérie. I. Morphologie, développement et affinités des Nématodes. Imp. S. Stamel, Alger, p. 221.

Skrjabin K. I. \& Schikhobalova N. P. 1951. Part I. Suborder Oxyurata Skrjabin, 1923. In: Key to Parasitic Nematodes. Volume 2. Oxyurata and Ascaridata, (Edited by Skrjabin K. I.), pp. 3-419. Akademiya Nauk SSSR Publishers, Moscow.

Stiles C. W. \& Hassal A. 1905. The determination of generic types and a list of round worm genera with their original and type species. Bulletin of the U.S. Department of Agriculture and Animals 79: 1-150.

Vevers C. M. 1923. Some new and little known helminths from British Guyan. Journal of Helminthology 1: 35-45. van Waerebeke D. 1978. Descripion de Cephalobellus ovumglutinosus $\mathrm{n}$. $\mathrm{sp}$. et de Leydinema portentosae $\mathrm{n}$. $\mathrm{sp}$. (Nematoda: Thelastomatidae), parasites intestinaux de blattes et redefinition du genre Leidynema Schenk, 1926. Revue de Nématologie 1: 151-163. 